\title{
Audit expectation gap and loan decision performance of bank officers in Iran
}

\begin{abstract}
This study examines the effect of accounting knowledge and experiences of Iranian bank officers on the audit expectation gap, and investigates whether the gap mediates (or explains) the individual factor-loan decision performance relationship. Copies of a structured questionnaire were distributed to 113 loan officers from five large commercial banks in Iran and responses of 111 bank officers were analysed. The results show the existence of a fairly large audit expectation gap among the Iranian bank loan officers, and accounting knowledge was found to significantly mitigate the extent of the gap. More importantly, this study found a highly significant negative relationship between the audit expectation gap and loan decision performance of the Iranian bank officers. Further analyses indicate that the audit expectation gap fully mediates the individual knowledge-performance relationship. The findings of this study have important policy implications for recruitment and training of the bank officers.
\end{abstract}

Keyword: Accounting knowledge; Audit expectation gap; Accounting experience; Iran; Bank officers; Loan decisions; Performance evaluation; Commercial banks; Recruitment; Training 